\title{
Future Library Building Trends Among Colleges and Universities
}

\author{
Dr. Muller is director of libraries, South- \\ ern Illinois University.
}

$\mathrm{I}^{\mathrm{T}}$ IS SAFE to predict that over one hundred million dollars is going to be spent by American institutions of higher education for the construction of new library buildings in the next five to Io years. In addition, perhaps forty million dollars will be spent for additions to existing structures. According to a survey conducted in the fall of 1949 by the A.C.R.L. Committee on College and University Library Buildings, 103 institutions are currently working on preliminary plans for new library buildings, and 84 institutions are planning additions to existing library buildings. About one half of the institutions reporting new buildings in the offing have completed preliminary drawings, and 60 per cent have made cost estimates.

\section{Cooperation}

Such a tremendous volume of construction calls for cooperation among librarians. By pooling their knowledge, their observations and their talents, they may be able to avoid the pitfalls to which the independent worker is often subject. The accompanying tabulation is designed to enable librarians and architects to locate institutions of similar size and nature if they feel that by exchanging their experiences, they can help each other. Such a use of the tabulation is eminently practical. Another possible use is that it may provide justification for not discontinuing the Cooperative Com- mittee on College and University Library Building Plans, which has been of inestimable benefit to the many institutions that participated in its deliberations since its establishment in 1944. ${ }^{1}$ If the Cooperative Committee continues in existence, it is likely to continue to be the meeting-ground chiefly for librarians and architects of very large institutions. There is much at stake in the planning of a large library building, and there still remains a sufficient number of large buildings in the early stages of planning to provide ample subject matter for discussion in future meetings of the $\mathrm{Co}$ operative Committee.

Nevertheless, it should not be overlooked that approximately 75 per cent of the library buildings expected to be constructed in the near future will cost less than one million dollars each. Cooperation among librarians in the planning of these smaller buildings is unquestionably desirable. These smaller buildings will generally provide storage facilities for not more than 200,000 volumes; and the number of readers to be accommodated in any one of these buildings will be less than 500 .

\section{Seating Capacity}

Present seating capacities are insufficient in many of the 103 libraries, especially in those of larger institutions. Only three out of 2 I institutions enroling 3300 or more stu-

\footnotetext{
1 The architects and librarians present at the 1950 meeting of the committee at Ann Arbor, Mich., reacted unfavorably to a suggestion that the committee might peared to have solved their library building problems.
} 


\section{Library Building Plans of Colleges and Universities January 1950}

Name of Institution

Indiana University, Bloomington ${ }^{1}$ University of Pennsylvania, Philadelphia ${ }^{2}$ Wayne University, Detroit.

Michigan State College, East Lansing ${ }^{3}$

University of Maryland, College Park

Louisiana State University, Baton Rouge ${ }^{4}$

University of Chicagos

University of Utah, Salt Lake City

University of Houston, Houston, Tex

Alabama Polytech. Institute, Auburn

Washington University, St. Louis, Mo.

Virginia Polytech. Institute, Blacksburg ${ }^{9}$.

Georgia Institute of Technology, Atlanta

North Carolina State College, Raleigh ${ }^{10}$

Butler University, Indianapolis, Ind.

Florida State University, Tallahasseei1

Youngstown College, Youngstown, Ohio

Rensselaer Polytech. Institute, Troy, N.Y.

University of Idaho, Moscow ${ }^{12}$

University of Wyoming, Laramie

Canisius College, Buffalo, N.Y.13

Carnegie Institute of Technology, Pittsburgh ${ }^{14}$

Fresno State College, Fresno, Calif.

Southern Illinois University, Carbondalels

St. Bernardine of Siena College, Loudonvill

Case Institute of Technology, Cleveland ${ }^{17}$

De Pauw University, Greencastle, Ind.

Texas College of Arts \& Industries, Kingsville

East Texas State Teachers College, Commerce ${ }^{18}$....

University of Portland, Portland, Ore.

Valparaiso University, Valparaiso, Ind 19

Southwest Missouri State College, Springfield

Upsala College, East Orange, N.J. 20

Wellesley College, Wellesley, Mass. 21

State Teachers College, Milwaukee, Wis.

Gonzaga University, Spokane, Wash.

Idaho State College, Pocatello

Colgate University, Hamilton, N.Y.

Wittenbers College, Springfe,d, Obio

Sinmons College, Bpringfeld, 4

Kansas State Teachers College, Emporis

Trinity University, San Antonio, Tex. ${ }^{25}$.

Trinity University, San Antonio, Tex.

Furman University, Greenville, S.C.2.

California Institute of Technology, Pasadena

Howard College, Birmingham, Ala.

State Teachers College, Cortland, N.Y. .

College of the Pacific, Stockton, Calif.

Beloit College, Beloit, Wis.

Swarthmore College, Swarthmore, $\mathrm{Pa}$

New York State Teachers College, Brockport

State Teachers College, California, $\mathrm{Pa}_{2}$.

Muskingum College, New Concord, Ohio

Trinity College, Hartford, Conn..$^{27}$

Pacific Union College, Angwin, Calif.

State Teachers College, Mansfield, $\mathrm{Pa}$

Whitman College, Wall a Walla, Wash

Anderson Coll.\& Theological Seminary, Anderson, Ind 28

Houghton College, Houghton, N.Y

Millsaps College, Jackson, Miss

West Virginia Wesleyan College, Buckhannon

College of St. Catherine, St. Paul, Minn.

Nebraska State Teachers College, Wayne ${ }^{29}$

\author{
Estimated \\ Cost
}

equipment)

Planned
for

Seats
to Be
Pro-
vided

Euivi- Prelim-
inary
inēiut,
1948 Plans
Drawn

Library in

Separate

Volumes Sais

Building Main
Now and Building, Build-
ing,

Completed

$\$ 4,000,000$

$2,000,000$
$4,000,000$

$1,000,000$

$1,600,000$

$1,000,000$

500,000

$2,500,000$

500,000

$6,000,000$

$2,000,000$
$1,500,000$

$1,500,000$

$2,500,000$

$1,500,000$

$1,500,000$

$1,500,000$

750,000

500,000

$1,000,000$

250,000

350,000

300,000

$1,000,000 \quad 1,000,000$

650,000
750,000

$1,000,000$

600,000

$2,000,000$

700,000

$2,300,000$

500,000

200,000

100,000

350,000

150,000

350,000

250,000

800,000

850,000

150,000

300,000

250,000

900,000

200,000

200,000

500,000

800,000

500,000

750,000

$1,000,000$

...........

$, 000,000$

850,000
350,000

$\ddot{2,3000,000}$

130,000

250,000

100,000

300,000

100,000

200,000

100,000

300,000

250,000

2000

1900

3000

2000

23,974

18,91

18,455

15,870

12,302

10,223
9519

$1200 \quad 8924$

24

1500

750

1250

950
800
200
1277

1277

600

....

$\mathbf{2 0 0}$

1200

1500

300
$\ldots$.

500

800

750

8692
7655

7655
7402

5546

5376

5227

5109

5109
4679

4679
4268

3634

3488

3457

3350

3347

3052

3002

2752
2567

2168

2099

2099
1970
1057

1957

1893
1800
1744
1715

600

750
250

250
500
400

300

300
800

500

100,000

$\because 00$

$1,000,000$

200,000

800

400,000

150,000

550

500,000

250,000

350

1642

1605

1528
1502

1468

1468

1422

1414

1400
1389

1389
1271

1271
1210

1162

1146

1061

1035

1013

944
908

908

907
856

856
835
827

816
790

300,000

350,000

500,000

200,000

.......

40,000

100,000

100,000

200

400

787

786

756

. Yes, 1907

Yes, 1891

No

Yes, 1925

Yes, 1931

Yes, 1926

Yes, 1912

Yes, 1935

Yes, 1908

Yes, 1904

Yes, 1905

Yes, 1906

Yes, 1926

No 1930

Yes, 1930

No

No

No 1923

No

No

No

Yes, 1933

Yes, 1904

No

Yes, 1908

No 1930

Yes, 1880

No

Yes, 1910

No

No

No

Yes, 1890

No

Yes, 1892

No 1003

Yes, 1903

Yes 1906

Yes, 1906

No

Yes

No

Yes, 1925

Yes, 1905

Yes, 1906

No

No 


\begin{tabular}{|c|c|c|c|}
\hline $\begin{array}{c}\text { Estimated } \\
\text { Cost } \\
\text { (including } \\
\text { equipment) }\end{array}$ & $\begin{array}{l}\text { Volumes } \\
\text { Planned } \\
\text { for }\end{array}$ & $\begin{array}{l}\text { Seats } \\
\text { to Be } \\
\text { Pro- } \\
\text { vided }\end{array}$ & $\begin{array}{c}\text { Enrol- } \\
\text { ment, } \\
1948\end{array}$ \\
\hline & & & 750 \\
\hline $\begin{array}{r}1,000,000 \\
700,000\end{array}$ & $\begin{array}{l}120,000 \\
100,000\end{array}$ & $\ldots$ & $\begin{array}{l}740 \\
736\end{array}$ \\
\hline 350,000 & 90,000 & 300 & 712 \\
\hline 350,000 & $\begin{array}{l}75,000 \\
75,000\end{array}$ & $\begin{array}{l}125 \\
200\end{array}$ & $\begin{array}{l}680 \\
659\end{array}$ \\
\hline 300,000 & 60,000 & 200 & 655 \\
\hline$\ldots \ldots \ldots$ & .......... & $\cdots$ & $\begin{array}{l}654 \\
633\end{array}$ \\
\hline 450,000 & 250,000 & 700 & 623 \\
\hline 150,000 & & $\ldots$ & $\begin{array}{l}616 \\
601\end{array}$ \\
\hline 200,000 & 100,000 & 300 & 600 \\
\hline 700,000 & 229,000 & 287 & 600 \\
\hline $\begin{array}{l}260,000 \\
341,000\end{array}$ & $\begin{array}{l}50,000 \\
75,000\end{array}$ & $\begin{array}{l}176 \\
150\end{array}$ & $\begin{array}{l}600 \\
549\end{array}$ \\
\hline & 75,000 & 400 & 532 \\
\hline 400,000 & 80,000 & 120 & 523 \\
\hline$\ldots \ldots \ldots \ldots$ & n........ & $\ldots$ & $\begin{array}{l}497 \\
485\end{array}$ \\
\hline 200,000 & 60,000 & 150 & 485 \\
\hline $\begin{array}{l}150,000 \\
450,000\end{array}$ & $\begin{array}{r}60,000 \\
100,000\end{array}$ & $\begin{array}{l}300 \\
250\end{array}$ & $\begin{array}{l}473 \\
455\end{array}$ \\
\hline 125,000 & 60,000 & 100 & 431 \\
\hline$\ldots \ldots \ldots \ldots$ & 75,000 & 250 & $\begin{array}{l}428 \\
426\end{array}$ \\
\hline 50,000 & & $\ldots$. & 388 \\
\hline ....... & 150,000 & & 369 \\
\hline$\ldots \ldots \ldots$ & 90,000 & 231 & 347 \\
\hline & 50,000 & & $\begin{array}{l}345 \\
329\end{array}$ \\
\hline$\cdots$ & ......... & ... & $\begin{array}{l}329 \\
307\end{array}$ \\
\hline 150,000 & 75,000 & 200 & 291 \\
\hline 50,000 & 100,000 & 100 & 266 \\
\hline 100,000 & 150,000 & 200 & $\begin{array}{l}234 \\
220\end{array}$ \\
\hline
\end{tabular}

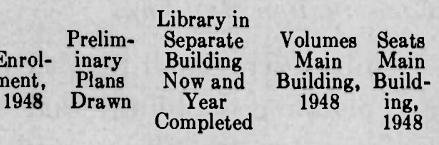

State Teachers College, Whitewater, Wis.

Goucher College, Baltimore, Md.80

Maryland State Teachers College, Towson

Lynchburg College, Lynchburg, $V_{a}$.

Humboldt State College, Arcata, Calif. ${ }^{31}$

University of Dubuque, Dubuque, Iow

Thiel College, Greenville, $\mathrm{Pa}^{32}$.

Mount St. Mary's College, Emmitsburg, M

Kentucky State College, Frankfort

Roanoke College, Salem, Va.

Eastern New Mexico University, Portales

Samuel Houston College, Austin, Tex. .

South western College, Winfield, Kan

Beaver College, Jenkintown, $\mathrm{Pa}$.

Kenyon College, Gambier, Ohio.

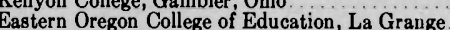

Seton Hill Con College of Education, La Grange

Aquinas College, Grand Rapids, Mich

College of St. Rose, Albany, N.Y.as.

Shepherd State College, Shepherdstown, W.V

State Teachers College, Oneonta, N.Y.

State Teace College Valley City 3 . 34

New Jersey State Teachers College, Glassboro

Principia College, Elsah, Ill.

Ad

Keuta College, College, Alamosa, Colo

D'Youville College, Buffalo, N.Y.

Nazareth College, Rochester, N.Y 35

Dakota Wesleyan University, Mitchall, S.D. $38 \ldots \cdots$

St. Mary College, Xavier, Kan.

Hollins College, Hollins College, $\mathrm{Va}{ }^{27}$

Blackburn College, Carlinville, Ill.

College of Med. Evangelists, Loma Linda, Calif.

Bennington College, Bennington, Vt

Coker College, Hartsville, S.C.

Blue Mountain College, Blue Mountain, Miss.

Georgian Court College, Lakewood, N.J.

Rocky Mountain College, Billings, Mont

30 Present building occupied by library since 1934.31 Maximum seating: 350.32 Maximum seating: 250. 33 Present building is a residence purchased 1939. 34 Architect eugaged. Maximum capacity: 80,000 volumes. 35 Plans drawn 10 years ago will probably be changed. 36 Plans are for museum, later to be used as library. 37 Maximum capacity: 100,000 volumes.

dents reported seating capacities in the main library of over io per cent of the enrolment. Out of 87 libraries reporting seating capacity, only 16 provided seats for 20 per cent or more of the 1948 student body in their old library buildings.

Library buildings of the future are expected to provide seats for not less than Io per cent of the 1948 enrolment. Relatively few buildings ( 18 out of 62 reporting) will provide seats for over 40 per cent of the current enrolment, and most of these will be for smaller institutions anticipating great increases in enrolment.

The larger institutions enroling 3500 students or more generally plan to seat between IO and 20 per cent of their students in their future main libraries. However, whereas most smaller institutions will merely dou- ble or treble their present seating capacities in their new buildings, several of the large institutions will provide from four to six times as many seats in their new main library buildings as were available in 1948 .

\section{Volume Capacity}

With the exception of the University of Pennsylvania, which is planning only the first unit of its new library building, all institutions reporting appear to provide book storage facilities in excess of what is available in their main libraries at present. Planned book storage capacity is most commonly two to three times as large as 1948 holdings. Only ro out of 54 institutions reporting on this aspect expect to have over four times as much book storage space in their new buildings as was needed for their 1948 holdings. 


\section{Combination Buildings}

Only a very small number of institutions are planning buildings that will combine facilities for the library with facilities for other campus functions. Where such combination buildings exist, expansion is often possible by gradually pushing the extraneous operations out of the building occupied by the library.

\section{Other Solutions}

In a few cases, expansion will take the form of separate storage facilities, such as are being planned for the University of Kentucky. On several campuses, the construction of departmental libraries will bring about relief in the main library building.

A few librarians faced with the problem of overcrowded stacks have found limited solutions in the preservation of records through microfilm and microcard, the substitution of storage stacks for regular stacks and, most ingeniously, the shelving of books by size and in cardboard boxes, as recommended by Fremont Rider. ${ }^{2}$

The problem of squeezing more readers into a given floor area is not quite so easily solved. In many libraries the lack of adequate facilities for readers seems much more serious than the lack of storage facilities for books.

\section{Why New Buildings?}

What are the forces that give rise to library building construction? In the case of additions to existing buildings, the answer is that expanded acquisitions programs and increased enrolments have often made existing buildings too small. Of the addi-

2 Rider, Fremont. Compact Book Storage. New York, Hadham Press, I949. tions to existing buildings currently planned, over one third are additions to buildings constructed within the last 20 years, indicating that many library planners of the recent past seriously underestimated future requirements. There are, however, a few institutions that have carefully designed programs of expansion. An outstanding example is the University of Illinois (1926), which constructed its first additional unit in 1928 , another one in 1929 and a third one in 1940.

Of the 103 new buildings, 62 are being planned for institutions that have never had a separate library building. Most of these institutions are small, with enrolments of fewer than Iooo students. A library building may enable them to become academically more respectable. Of the $4 \mathrm{I}$ buildings that are to replace existing buildings, only 18 will replace buildings that are over 40 years old.

Summarizing the forces that make for new library building construction, the most important one seems to be the current nonexistence of a library building on many campuses. Three other influences are expanded acquisitions programs, unprecedented increases in student enrolment and obsolescence of old buildings.

The accompanying tabulation includes only those institutions which returned the questionnaire that was mailed to all institutions listed in American Universities and Colleges. $^{3}$ The tabulation is the second in a series of three, the first of which appeared in July. ${ }^{4}$ The third and final tabulation will list library buildings completed between I 929 and 1949.

3 Brumbaugh, A. J., ed. American Universities and Colleges, 5 th ed. American Council on Education, ${ }^{1949}$ Muller, Robert H. "Library Building Construction Among Cólleges and Universities, 1950." College and Research Libraries, I1:259-61, July 1950. 